\title{
ACTA ENTOMOLOGICA MUSEI NATIONALIS PRAGAE
}

\section{Leptomorphus sevciki sp. nov., a remarkable new wasp-mimicking fungus gnat from Brunei (Diptera: Mycetophilidae)}

\author{
David KASPŘÁK ${ }^{1)}$, Christopher J. BORKENT ${ }^{2)}$ \& Rodzay Abdul WAHAB ${ }^{3)}$ \\ ${ }^{1)}$ Department of Biology and Ecology \& Institute of Environmental Technologies, Faculty of Science, \\ University of Ostrava, Chittussiho 10, CZ-710 00 Ostrava, Czech Republic; e-mail: davidkasprak@gmail.com \\ ${ }^{2)}$ California State Collection of Arthropods, California Department of Food and Agriculture, 3294 Meadowview \\ Rd. Sacramento, CA 95831, USA; e-mail: chris.borkent@gmail.com \\ 3) Universiti Brunei Darussalam, Institute for Biodiversity and Environmental Research, Tungku Highway, \\ BE1410, Brunei Darussalam; e-mails: rodzay.wahab@ubd.edu.bn
}

\begin{abstract}
A new species of Mycetophilidae (Diptera), Leptomorphus sevciki sp. nov., is described from primary lowland rainforest in Ulu Temburong National Park in Brunei. The type specimens were reared from pupae hanging from an unidentified wood encrusting fungus growing on a fallen tree. DNA sequences, including fragments of the nuclear $28 \mathrm{~S}$ region and the mitochondrial $12 \mathrm{~S}, 16 \mathrm{~S}$, $\mathrm{CytB}$ and $\mathrm{COI}$ (barcode region) genes, were extracted from two specimens, including the holotype.
\end{abstract}

Key words. Diptera, Sciaroidea, Mycetophilidae, Sciophilinae, Leptomorphus, COI barcode, DNA sequences, fungus gnats, mimicry, new species, taxonomy, Borneo, Brunei, Oriental Region

\section{Introduction}

The genus Leptomorphus Curtis, 1831 is a relatively species-rich genus of large fungus gnats (Diptera: Mycetophilidae) with some 45 described species worldwide (BORKENT \& WheELER 2012, PAPP \& ŠEvČ́́ 2011). It belongs to the subfamily Sciophilinae, where it forms a sister group to Eudicrana Loew, 1870 (Borkent \& WheEler 2013, ŠEvčík et al. 2013). The Oriental species have recently been studied by PAPP \& ŠEVČ́́ (2011), who described 8 new species, and by BORKENT \& WHEELER (2012) who described three new species from the region and provided a phylogenetic hypothesis of the relationships between all Leptomorphus 
species. The two earliest described Oriental species, L. ornatus Brunetti, 1912 and L. chaseni Edwards, 1933, are only known from female specimens. As discussed in BORKENT \& WHEELER (2012), their relationship to other species in the genus remains tentative, as the identification and phylogenetic placement of the Oriental species of this genus is based principally on the complex male terminalia.

The insect fauna of Brunei is becoming increasingly more studied and new species are discovered regularly (see e.g. GABRIš et al. 2017; GNEZDIlov 2015; JeŽEK et al. 2015; KUŘAVOvÁ et al. 2017a,b). However, the fungus gnat fauna (Diptera: Sciaroidea) still remains mostly unknown, with only several species of Diadocidiidae, Keroplatidae and Mycetophilidae described or recorded (see HipPA \& ŠEvČíK 2010; PAPP \& ŠEvČíK 2005, 2011; ŠEvČíK \& HipPA 2010; ŠEvČí 2012; ŠEvČíK \& PAPp 2009; Š́EvČíK et al. 2014a; HipPA et al. 2016). In the years 2013-2015, we were able to study the fungus gnat community in a primary lowland rainforest at the Kuala Belalong Field Studies Centre (KBFSC) in Ulu Temburong National Park, Brunei. During the second (2014) stay at the field station we discovered, observed, and collected a remarkable new species of Leptomorphus, which is described here.

\section{Material and methods}

The adults of the new species were collected in January 2014, by rearing pupae found hanging from a fallen tree (Fig. 15) in the surroundings of KBFSC (for the description of study area see ŠEvČ́́ et al. 2014a). The specimens were either pinned or preserved in $80 \%$ ethanol. A total of 7 males and 4 females were examined, with the holotype and one male paratype specimen first being incubated overnight in isolation buffers and enzymes for DNA isolation.

The holotype and two paratypes (one male and one female) are deposited in the collection of the University of Brunei Darussalam (UBD), Bandar Seri Begawan, Brunei. One paratype male is deposited in the National Museum, Prague, Czech Republic (NMPC) and two paratypes (one male and one female) in the California State Collection of Arthropods (CSCA). The other paratypes (three males and one female) and immature material are deposited in the reference collection of the Ševčík Lab, University of Ostrava, Czech Republic (JSL-UOC).

The general morphological terminology of adults principally follows that of CUMMING \& Wood (2009) and the genitalic terminology follows that of SøLi (1997). The measurements were taken from the specimen stored in ethanol using an Olympus SZ stereomicroscope and QuickPHOTO Camera 3.0 software (PROMICRA 2015). The male genitalia were observed and drawn with an Olympus CX41 microscope equipped with a drawing tube. All photographs were taken using a Canon EOS 1100D camera.

The mitochondrial DNA markers $12 \mathrm{~S}, 16 \mathrm{~S}$, cytochrome oxidase I (COI), and cytochrome B (cytB), along with nuclear DNA marker 28S, were extracted, amplified, and sequenced using the protocols in ŠEvČík et al. (2013, 2014b, 2016). The sequences are deposited in the GenBank (www.ncbi.nlm.nih.gov/Genbank) database (accession numbers below).

Video with the shots of larval behaviour and the pupae of L. sevciki on the underside of a $\log$ at the type locality is available on YouTube (https://youtu.be/89HN2255ZOs), Vimeo (https://vimeo.com/217065105), or on request from the first author. 


\section{Species description}

\section{Leptomorphus sevciki Kaspřák \& Borkent sp. nov.}

Type material. Hоцотур: đa, BRUNEI: Ulu Temburong National Park, Kuala Belalong Field Studies Centre, primary forest, $4^{\circ} 33^{\prime} 07.5^{\prime \prime} \mathrm{N} 115^{\circ} 09^{\prime} 26.8^{\prime \prime} \mathrm{E}, 14.1 .2014$, J. Ševčík and D. Kasprák leg., ex pupa (coll. UBD, in ethanol). Specimen voucher number JSS25a-LS1. PARATYPES: BRUNEI: Ulu Temburong National Park, Kuala Belalong Field Studies Centre, primary forest, $4^{\circ} 33^{\prime} 07.5^{\prime \prime} \mathrm{N} 115^{\circ} 09^{\prime} 26.8^{\prime \prime} \mathrm{E}, 8-20.1 .2014$, ex pupa, ठठ (JSS25c-LS2) and $q$ (JSS25e-LS3) (coll. UBD, in ethanol); 3 $\delta$ (pinned, JSS25-LS4, JSS25-LS5, JSS25-LS6), 1 q (pinned, JSS25-LS7) and $1 \uparrow$ (in ethanol, JSS25f-LS8) (coll. JSL-UOC); $1 \precsim$ (JSS25-LS9) and 1 (JSS25-LS10) (coll. CSCA, pinned); and $1 \hat{\delta}$ (JSS25-LS11) (coll. NMPC, pinned).

Immature material not included in type series: BRUNEI: Ulu Temburong National Park, Kuala Belalong Field Studies Centre, primary forest, $4^{\circ} 33^{\prime} 07.5^{\prime \prime} \mathrm{N} 115^{\circ} 09^{\prime} 26.8^{\prime \prime} \mathrm{E}, 8-20.1 .2014,2$ L and $2 \mathrm{P}$ (coll. JSL-UOC, in ethanol).

Diagnosis. The only extant species of Leptomorphus with the following combination of characters: male antennae covered in long setae (unique in the genus); yellow V-shaped marking on the dorsal side of dark brown scutum; katepisternum yellow and brown; metakatepisternum partially dark brown; abdominal segments swelling towards the apex of terminalia. Sternite 9 with medioventral lobe and a pair of lateroventral lobes bearing four dark megasetae apically.
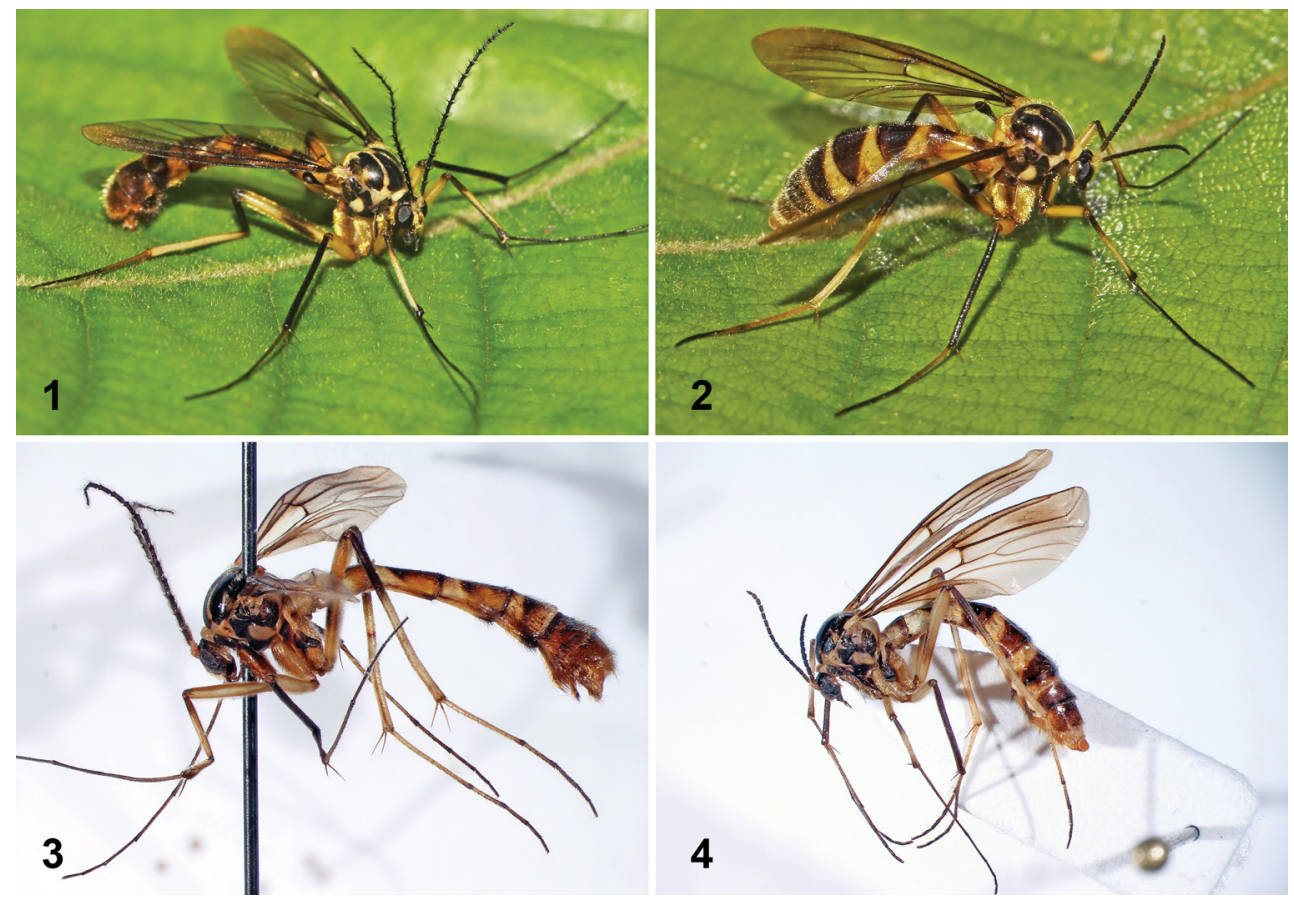

Figs 1-4. Leptomorphus sevciki sp. nov.: 1 - male (Photo: J. Ševčík); 2 - female (Photo: J. Ševčík); 3 - male, habitus; 4 - female, habitus. 
Description. Male. Body length $14.3 \mathrm{~mm}$. General colouration dark brown and dark yellow, yellow-orange and brown striped abdomen (Fig. 1, 3).

Head. Dark brown, light brown laterally with many long setae. Ocelli yellow, in a straight line. Face yellow. Flagellomeres dark brown, densely covered with long, fine, dark brown setae (Fig. 5). Basal part of first flagellomere yellow. Scape and pedicel yellow, setae on at least the anterior surface. Face and clypeus covered with many long setae. Clypeus and palpus light brown.

Thorax. Mostly dark brown. Scutum dark brown with dorsal yellow V-shape marking, covered with fine hairs, several long light setae along margin (Fig. 6). Scutellum light brown, with many short setae. Antepronotum, proepisternum, anepisternum, anepimeron and laterotergite dark brown. Proepisternum covered with light setae. Paratergite light to dark brown. Laterotergite with several long setae. Anepisternum and anepimeron bare. Katepisternum anterior dark brown and posterior yellow, bare. Metakatepisternum partially dark brown, bare. Mediotergite yellow, bare. Margin of anterior and posterior spiracles yellow with yellow trichia. Haltere: stem yellow, knob dark brown.

Wing (Fig. 7). Hyaline, membrane densely covered with irregularly arranged macrotrichia. Cell among base of $\mathrm{R}_{1}$, crossvein $\mathrm{r}-\mathrm{m}$ and $\mathrm{M}$ bare, sector between veins $\mathrm{M}$ and $\mathrm{CuA}$ bare except apically. Apical shading dark brown but fading towards apex and posterior margin (pale brown apical wing shading not reaching to wing tip), running from anterior to posterior wing

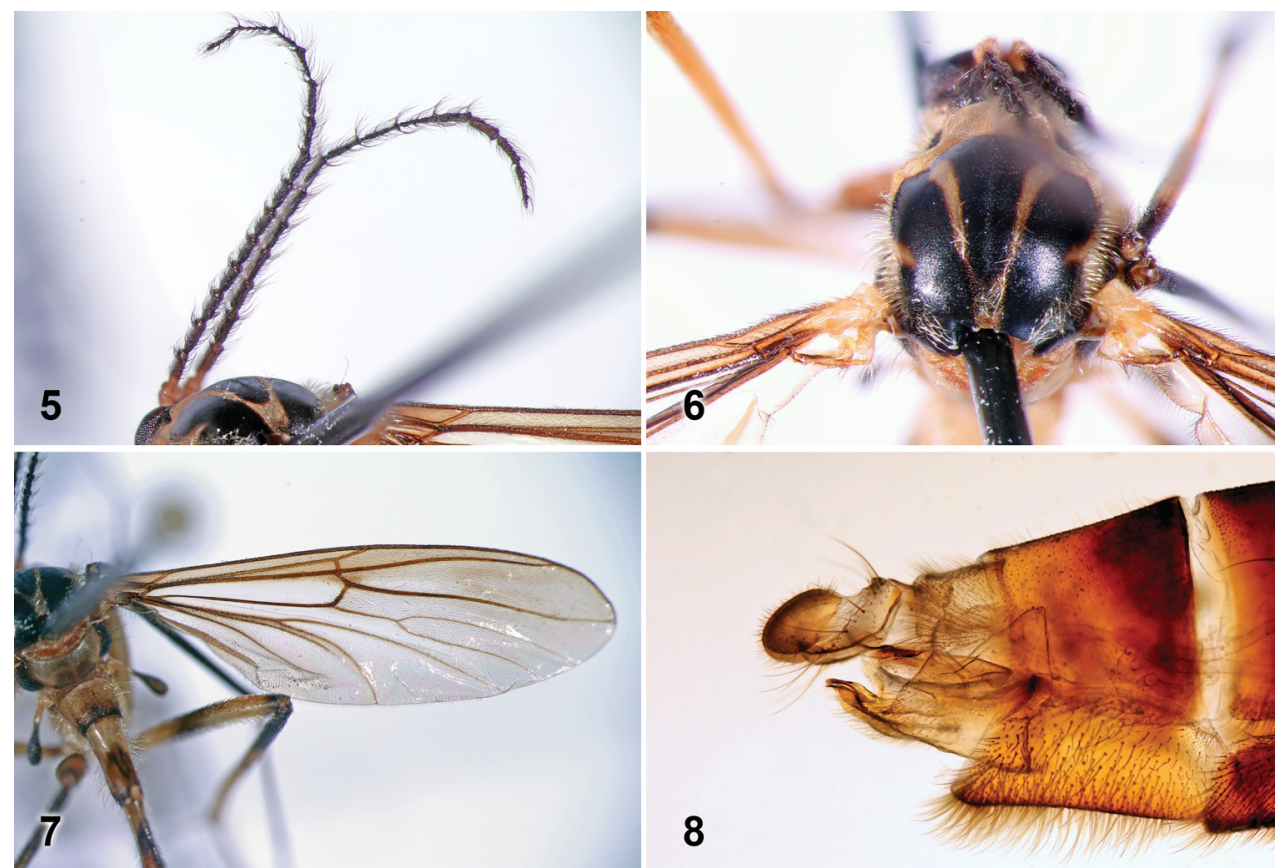

Figs 5-8. 5-7 - Leptomorphus sevciki sp. nov., male: 5 - antennae; 6 - thorax, V-shape mark; 7 - wing; 8 - female, genitalia, lateral view. 
margin, beginning halfway along $\mathrm{R}_{5}$. Medial macula small, only around Rs. Costa ending at tip of $\mathrm{R}_{5}$. Sc short, ending in costa beyond base of $\mathrm{r}-\mathrm{m}$. Vein sc-r ending beyond Rs. Vein $\mathrm{R}_{4}$ absent. Vein $\mathrm{R}_{5}$ slightly concave for entire length. Crossvein $\mathrm{r}-\mathrm{m}$ relatively long (twice as long as radial sector). Apex of crossvein r-m lighter than base. Apices of $\mathrm{M}$ and $\mathrm{CuA}$ veins clearly reaching wing margin. Point of furcation of $\mathrm{CuA}$ and $\mathrm{M}_{4}$ well before crossvein $\mathrm{r}-\mathrm{m}$. CuP thick, slightly shorter than $\mathrm{A}_{1}$. $\mathrm{A}_{1}$ distinct.

Legs. Coxae principally yellow, forecoxa dark brown and hind coxa with anterior dark brown mark. All trochanters brown. Femora yellow, dark long setae laterally, hind femur brownish, dense setulae and dark brown mark beginning one third of length of hind femur and reaching beyond midpoint. Fore tibia yellow with basal brown mark, dense row of anteroventral bristles
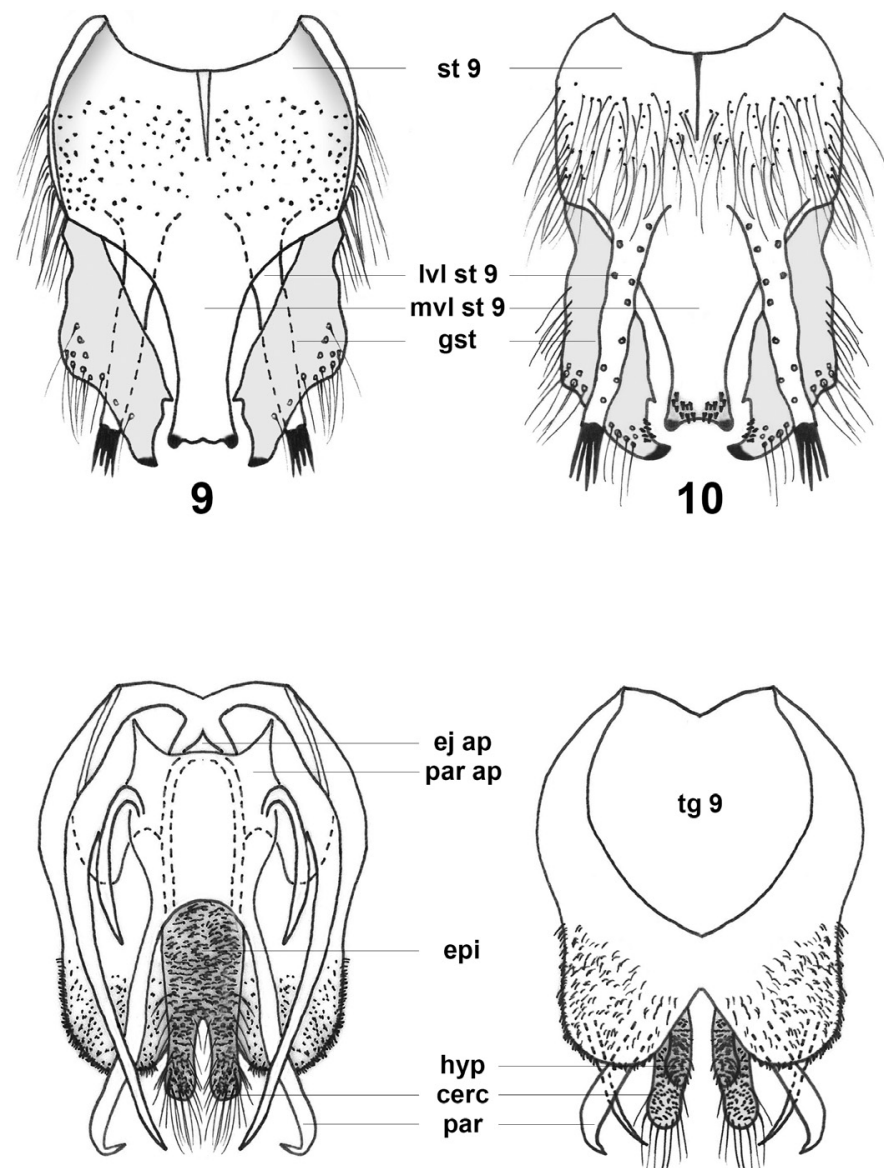

11

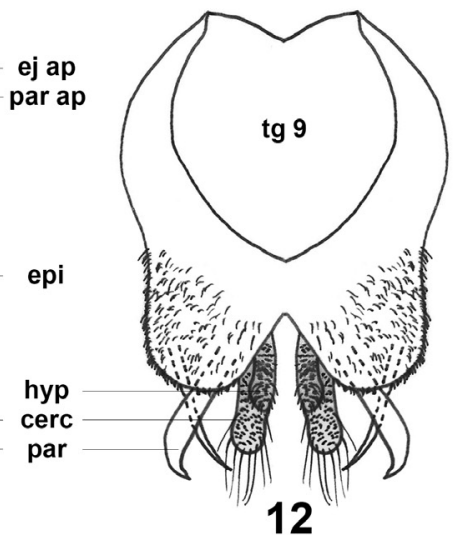

Figs 9-12 - Leptomorphus sevciki sp. nov., male, terminalia: 9 - ventral part, internal view; 10 - ventral part, external view; 11 - dorsal part, internal view; 12 - dorsal part, external view. Abbreviations: cerc = cercus; ej ap = ejaculatory apodeme; epi = epiproct; gst = gonostylus; hyp = hypoproct; mvl st $9=$ medioventral lobe of sternite $9 ; 1 \mathrm{vl}$ st 9 $=$ lateroventral lobe of sternite $9 ;$ par = paramere; par ap = parameral apodeme; st $9=$ sternite $9 ; \operatorname{tg} 9=$ tergite 9 . 
absent. Mid tibia entirely dark brown with irregular rows of short dark bristles. Hind tibia yellow with basal dark brown mark longer than fore tibia basal mark. Tarsi dark brown. First and second hind tarsomeres yellowish to light brown with dark brown apex.

Abdomen. Tergites principally dark brown, tergites 1-6 with anterior third light brown. Tergites 7-8 dark brown. Sternites brown. Posterior 4 segments of abdomen noticeably swollen relative to other segments (Fig. 3).

Terminalia (Figs 9-12). Light brown, apex of gonostyli and medioventral lobe of sternite 9 darker. Sternite 9 sclerotized, medially covered with long setae, with medioventral lobe and a pair of lateroventral lobes, dark brown suture mediobasally. Medioventral lobe bare, as long as sternite 9, covering cerci, with two rounded processes bent ventrally and apical dark blunt bristles. Lateroventral lobe with bumpy margin, with several long setae and four dark apical megasetae. Tergite 9 sclerotized, densely covered with short setae and V-shaped indentation on the apex, bare transparent tapering part of base. Gonostyli bare, except lateral margin with long setae, dark blunt bristles on medial margin of apex, lateral rounded process and medial hooked process. Apex of gonostylus dark, tapering towards apex. Cerci and hypoproct covered with short trichia and long apical setae. Parameres strongly hooked at apex.

Female (Figs 2, 4). Similar to male with following differences: antennal setae short, hind femur lighter with brown mark only anteriorly, genitalia lighter. Tergite 9 yellow, with long setae. Tergite 10 yellow, row of several long and shorter setae on posterior margin. Cerci brown, setose. Gonopore 9 brown. Gonocoxite 8 posteriorly brown and setose (Fig. 8).

DNA sequences. DNA sequences taken from the holotype and one male paratype are deposited in the GenBank database, with following GB accession numbers: JSS25a-LS1 (holotype): 12S: MF045798, 16S: MF045800, COI: MF045803, cytB: MF045805, 28S: n/a; JSS25cLS2 (paratype): 12S: MF045799, 16S: MF045801, COI: MF045804, cytB: MF045806, 28S: MF045802.

Etymology. This species is named after Jan Ševčík, a specialist on Diptera associated with fungi and supervisor of David Kasprák's Ph.D. study, who was the first to spot the specimens of the new species in Ulu Temburong National Park.

Biology. The larvae and pupae of the new species were found on the underside of a log over a small brook. The larvae spun a silk sheet over the surface of an unidentified wood encrusting fungus (Fig. 13, Video: https://youtu.be/89HN2255ZOs). The pupae were hanging from a singly anchored $3-5 \mathrm{~cm}$ long yellowish thread, bearing a drop of brownish liquid (Fig. 14, Video: https://youtu.be/89HN2255ZOs). The behaviour of the flying adults and their colouration were reminiscent of wasps or ichneumonids (Hymenoptera).

\section{Discussion}

The new species can be easily distinguished from its congeners by its robust size, male antennae with distinct setae, the colouration of the thorax, and specific male and female terminalia. According to the key by BORKENT \& WhEELER (2012), the new species runs to couplet 23 and does not continue, because of two-coloured preepisternum 2 (katepisternum), metepisternum partially dark brown, wing with apical spot and last three abdominal segments swollen. Brown katepisternum, metepisternum partially brown or light brown, wing 

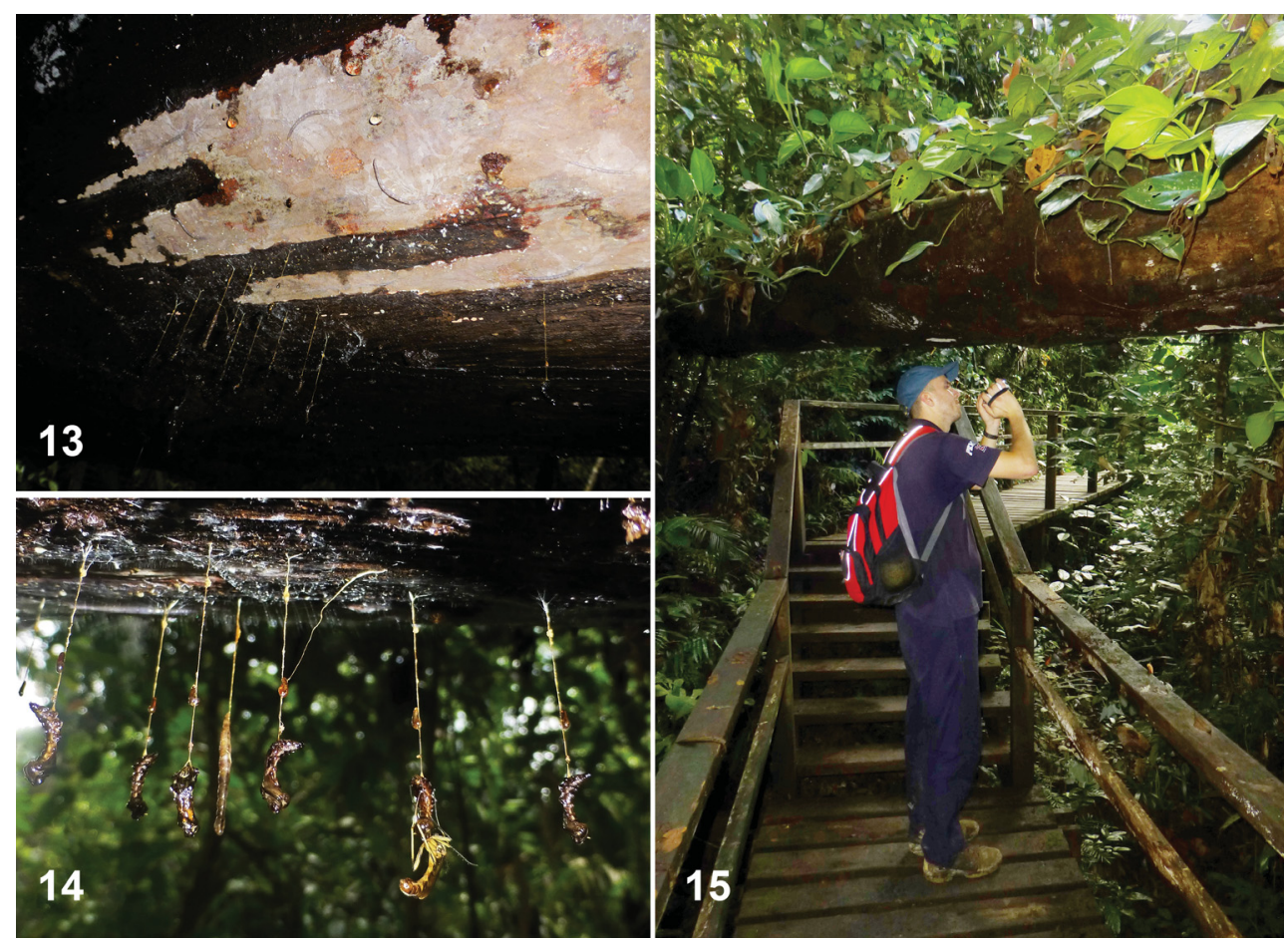

Figs 13-15. 13 - The larvae of Leptomorphus sevciki sp. nov. on the surface of an unidentified wood encrusting fungus growing on a $\log$ in a rainforest in Brunei. 14 - The pupae of L. sevciki sp. nov., on the underside of a log in a rainforest in Brunei. 15 - The fallen tree over a pathway with hanging pupae in Ulu Temburong National Park in Brunei. (Photos: J. Ševčík).

without apical spot and swollen 3-5 abdominal segments are character states present in $L$. tabatius Borkent, 2012, L. chaseni, and L. tagbanua Borkent, 2012. Yellow katepisternum and metepisternum, wing with pale brown apical spot and abdominal segment relatively with the same thickness are characters common with L. babai Sasakawa, 1960, L. titiwangsensis Borkent, 2012 and L. ornatus.

Due to this combination of characters, L. sevciki is apparently not closely related to the Oriental species described by PAPP \& ŠEvČíK (2011). The species from their "ascutellatus" group were quite common in the samples taken at Kuala Belalong Field Studies Centre. Leptomorphus sevciki appears to be more closely related to members of the L. walkeri or L. furcatus groups of BORKENT \& WHEELER (2012). We also captured one female in 2015 at the same locality which appears to represent a different species related to L. sevciki, indicating that there exists at least one more species from this group in Borneo.

The striking yellow and dark colouration, together with swollen abdomen in both the male and female (Figs 1, 2), suggest wasp-mimicking. A possible model could be either a true wasp, ichneumonid or other hymenopteran. This colour pattern is also present in several 
other Leptomorphus species (BORKENT \& WHEELER 2012). Within Sciaroidea, this phenomenon has also been reported for two Australasian Keroplatidae, Nicholsonomyia Tonnoir, 1929 and Tamborinea Matile, 1981 (see TonNoir 1927 and Matile 1981).

As discussed in BORKENT \& WHEELER (2012) all members of this genus where the immature biology is known pupate while hanging from a silk line, either as a pendulum or hammock. As shown in Fig. 14, L. sevciki also pupates hanging from a silk line in a pendulum fashion. EBERHARD (1970) reported that males are attracted to female pupae, hanging on them and fighting off challengers as they await the emergence of the female. This might explain the male of L. sevciki hanging on the pupa in Fig. 14.

\section{Acknowledgements}

We are grateful to Jan Ševčík (University of Ostrava) for his help with descriptions of the new species, for providing photographs and assistance in the field. We also thank the cooks and other staff of Kuala Belalong Field Studies Centre for their care of us in the Brunei rainforest. Drs. P. Chandler (UK) and L. Papp (Hungary) are thanked for their valuable comments on a previous version of the manuscript. This study was supported by the projects Support for science and research in the Moravian-Silesian Region 2013 (RRC/05/2013) and Innovation of ecological studies by complementary fusion of courses between Palacký University and University of Ostrava (CZ.1.07/2.2.00/28.0149).

\section{References}

BORKENT C. J. \& WHEELER T. A. 2012: Systematics and phylogeny of Leptomorphus Curtis (Diptera: Mycetophilidae). Zootaxa 3549: 1-117.

BORKENT C. J. \& WHEELER T. A. 2013: Phylogeny of the tribe Sciophilini (Diptera: Mycetophilidae: Sciophilinae). Systematic Entomology 38: 407-427. doi: 10.1111/syen.12002

CUMMING J. M. \& WOOD D. M. 2009: Morphology and terminology. Pp. 9-50. In: BROWN B. V., BORKENT A., CUMMING J. M., WOOD D. M., WOODLEY N. E. \& ZUMBADO M. A. (eds): Manual of Central American Diptera. Volume 1. NRC Research Press, Ottawa, 714 pp.

EBERHARD W. G. 1970: The natural history of the fungus gnats Leptomorphus bifasciatus (Say) and L. subcaeruleus (Coquillett) (Diptera: Mycetophilidae). Psyche 77: 361-383. doi: 10.1155/1970/81283

GABRIŠ R., TRNKA F., WAHAB R. A. \& KUNDRATA R. 2017: Taxonomic revision of the endemic Bornean genera Anexodus Pascoe and Pantilema Aurivillius (Coleoptera, Cerambycidae, Lamiinae). ZooKeys 669: 29-51. doi: $10.3897 /$ zookeys.669.12608

GNEZDILOV V. M. 2015: Description of a new genus and species of Hemisphaeriini from Brunei with an identification key to the Bornean species of the tribe (Hemiptera: Fulgoroidea: Issidae). Acta Entomologica Musei Nationalis Pragae 55: 9-18.

HIPPA H., KASPŘÁK D., KAHAR R. S. \& ŠEVČÍK J. 2016: Two new Oriental species of Paramanota Tuomikoski (Diptera: Mycetophilidae), with DNA sequence data. Raffles Bulletin of Zoology 64: 360-367.

HIPPA H. \& ŠEVČÍK J. 2010: Notes on Oriental and Australasian Manotinae (Diptera, Mycetophilidae), with the description of thirteen new species. Zootaxa 2333: 1-25.

JEŽEK J., WAHAB R. A. \& ŠEVČÍK J. 2015: Two new species of Sycorax (Diptera: Psychodidae: Sycoracinae) from the Oriental Region. Zootaxa 4057: 539-550. doi: 10.11646/zootaxa.4057.4.4

KUŘAVOVÁ K., ŠIPOŠ J., WAHAB R. A., KAHAR R. S. \& KOČÁREK P. 2017a: Feeding patterns in tropical groundhoppers (Tetrigidae): a case of phylogenetic dietary conservatism in a basal group of Caelifera. Zoological Journal of the Linnean Society 179: 291-302. doi: 10.1111/zoj.12474 
KUŘAVOVÁ K., WAHAB R. A. \& KOČÁREK P. 2017b: External morphology of the antennae and sense organs of the groundhopper Discotettix belzebuth (Orthoptera, Tetrigidae). Zoologischer Anzeiger 266: 120-128. doi: 10.1016/j.jcz.2016.11.003

MATILE L. 1981: A new Australian genus of Keroplatidae with pectinate antennae (Diptera: Mycetophiloidea). Journal of the Australian Entomological Society 20: 207-212.

PAPP L. \& ŠEVČÍK J. 2005: New taxa of Diadocidiidae (Diptera) from the Oriental region. Acta Zoologica Academiae Scientiarum Hungaricae 51: 329-341.

PAPP L. \& ŠEVČÍK J. 2011: Eight new Oriental and Australasian species of Leptomorphus (Diptera: Mycetophilidae). Acta Zoologica Academiae Scientiarum Hungaricae 57: 139-159.

SØLI G. E. E. 1997: The adult morphology of Mycetophilidae (s.str.), with a tentative phylogeny of the family (Diptera, Sciaroidea). Entomologica Scandinavica, Supplement 50: 5-55.

ŠEVČÍK J. 2012a: Pseudochetoneura gen. nov., a peculiar new genus from Ecuador, with notes on Chetoneura (Diptera: Keroplatidae). Acta Entomologica Musei Nationalis Pragae 52: 281-288.

ŠEVČÍK J. 2012b: Terocelion gen. nov., a new Oriental genus of Keroplatidae (Diptera) with pectinate antennae. Acta Entomologica Musei Nationalis Pragae 52: 495-503.

ŠEVČÍK J. \& HIPPA H. 2010: New species of Chalastonepsia and Pectinepsia gen. nov. (Diptera: Mycetophilidae) from the Oriental and Australasian Regions. Acta Entomologica Musei Nationalis Pragae 50: 595-608.

ŠEVČÍK J., HIPPA H. \& WAHAB R. A. 2014a: Diversity of Manota Williston (Diptera, Mycetophilidae) in Ulu Temburong National Park, Brunei. ZooKeys 428: 57-77. doi: 10.3897/zookeys.428.7912

ŠEVČÍK J., KASPŘÁK D., MANTIČ M., FITZGERALD S., ŠEVČÍKOVÁ T., TÓTHOVÁ A. \& JASCHHOF M. 2016: Molecular phylogeny of the megadiverse insect infraorder Bibionomorpha sensu lato (Diptera). PeerJ 4 (e2563): 1-30. doi: 10.7717/peerj.2563

ŠEVČÍK J., KASPŘÁK D., MANTIČ M., ŠEVČÍKOVÁ T. \& TÓTHOVÁ A. 2014b: Molecular phylogeny of the fungus gnat family Diadocidiidae and its position within the infraorder Bibionomorpha (Diptera). Zoologica Scripta 43: 370-378. doi: 10.1111/zsc.12059

ŠEVČÍK J., KASPŘÁK D. \& TÓTHOVÁA. 2013: Molecular phylogeny of fungus gnats (Diptera: Mycetophilidae) revisited: position of Manotinae, Metanepsiini, and other enigmatic taxa as inferred from multigene analysis. Systematic Entomology 38: 654-660. doi: 10.1111/syen.12023

ŠEVČÍK J. \& PAPP L. 2009: Microkeroplatus, a new genus of Keroplatidae (Diptera) from the Oriental region. Acta Zoologica Academiae Scientiarum Hungaricae 55: 339-347.

TONNOIR A. L. 1929: Australian Mycetophilidae. Synopsis of the genera. Proceedings of the Linnean Society of New South Wales 54: 584-614. 
